\title{
The English ars morendi: its Protestant Transformation
}

\author{
DAVID W. ATKINSON
}

In the face of war, high infant mortality, and the ravages of plague, death to men living in the sixteenth and seventeenth centuries was a vivid reality, an ever-present reminder of the futility of life and of man's helplessness at the hands of forces he could neither understand nor control. Shakespeare's Claudio expresses a sentiment with which few men would disagree when he laments how the "most loathed worldly life" is "a paradise / To what we fear of death." But much as man bemoaned the capriciousness of life and tried to turn his back on death, he also looked to do something about preparing himself for an event from which he knew there was no escape. Thus was born the literary tradition of the ars moriendi, which aimed to prepare man to stand in God's judgment and to give him the strength he needed to face death.

The tradition of the "art of dying well" began in a humble way in the early fifteenth century with the anonymous Tractatus artis bene moriendi. As Sister Mary Catharine O'Connor has demonstrated, this anonymous little treatise spread with amazing speed throughout Europe, ${ }^{2}$ and was translated into practically every major European language. English translations of the Tractatus are extant in manuscripts dating from $1450,{ }^{3}$ and Caxton translated and published the work as The Craft of Dying Well in 1490. In England, moreover, writers such as Erasmus, Thomas Lupset, and Thomas Elyot produced works on preparing for death, which, influenced by the cultural milieu of the early Renaissance, far exceeded both in intellectual and literary accomplishment the dry and mechanical Craft. The most important development of the English ars moriendi was not, however, its transformation from a pious medieval tract into a classical moral essay. ${ }^{4}$ In England the majority of works on preparing to die were produced, not by the Christian Humanists, nor even by Catholics, but by Protestants who retained what was valuable of the established tradition and adapted it to a theological framework based on Calvin rather than Aquinas. Here, in this modification of an originally Catholic tradition, one finds the most important development in the English ars moriendi. It resulted in a rich corpus of instructional literature possessing a number of distinctive features that reveal much about late sixteenth- and seventeenth-century English Protestant spirituality. 


\section{2 / Renaissance and Reformation}

The relationship between the ars moriendi and English Protestantism is best revealed in the devotional thrust of Protestant works in this corpus. In this regard it is possible to make one rather obvious, though slightly misleading, distinction between the Catholic and Protestant works. While Catholic ars works instructed man how to die so that he could merit eternal life, Protestant works, influenced by the Calvinist theology of the English Church, proceed on the assumption that man's major concern is to gain assurance of election. This is the case, for example, in Thomas Becon's Sycke Mans Salue (1561), one of the bestsellers of the English ars tradition. Becon's quasi-dramatic work centres on the deathbed, as Philemon and his companions visit Epaphroditus to comfort him in his final agony. The suffering man cries out for the spiritual assurance central to the Calvinist: "What if I be not of the number of those whom God has predestinat to be saued." And his friends assure him, according to the best Calvinist orthodoxy, that faith, repentance, and a virtuous life, as well as the ability to withstand the final temptations of the deathbed, are "an euident testimonye of your saluation, and that god hath predestinat, and tofore appoynted you vnto euerlasting lyfe."5

Despite the popularity of Becon's work, however, A Sycke Mans Salue does not fully represent the devotional perspective of the English Protestant ars moriendi, nor is it wholly accurate to say that the Church of England was purely Calvinist in its doctrinal orientation. Rather the majority of English Protestant ars works reflect the development of an Arminian party, which espoused freewill and universal grace in opposition to the predestination and limited election of the Calvinists. Indeed the notion that man had no say in his spiritual destiny was repugnant to many Englishmen and became in time a divisive force in the English Church. On the one hand, there was the specifically Calvinist thrust of the Thirty-nine Articles of the Church of England and Whitgift's Lambeth Articles; on the other, there were men such as Peter Baro, John Donne, and Lancelot Andrewes, for whom William Laud clearly speaks when he writes that if predestination means that "God from all eternity reprobates by far the greater part of mankind to eternal fire, my very soul abominates it . . . it makes God, the God of all mercies, to be the most fierce and unreasonable tyrant in the world."6

This doctrinal conflict necessarily posed a problem for the English Protestant ars writers, whose immediate concern was saving souls rather than arguing fine points of theology. It was not, however, an insurmountable problem, and one finds that English Protestant works on preparing for death fall into two categories determined by how they reconcile the confusing doctrine of English Churchmen with the specific and more immediate devotional needs of the individual Christian. Most Protestant ars writers did not appear to worry about such contradiction and their works manifest the 
Church's general doctrinal confusion, while those of a second group stressed Christian fundamentals and consciously avoided mentioning particular points of doctrine.

Two works in particular reveal the extent to which some English Protestant ars writers were willing to ignore doctrinal contradiction, James Cole's Of Death A True Description (1629) and John Moore's A Mappe of Mans Mortalitie (1617). Much of Cole's treatise is devoted to answering the question that had so preoccupied Becon: "How shall I know certainly ... whether I be one of those, which God hath called \& chosen to enjoy his gracious promises, or of those that haue nothing to doe with them?" "In recounting the various signs of election Cole makes clear that salvation is the sole responsibility of God: "Nor can . . . true repentance," he says, "proceede from any but from God, who is the fountaine of all good. If then he send vs true repentance, hee endeauors our Saluation; if he endeuour it, he will performe it." ${ }^{8}$ Likewise John Moore in A Mappe explicitly rejects freewill when discussing "the assurance and certaintie which Gods Children haue of their saluation"; 9 he writes that "God doth worke in the hearts of men to incline their wills which way hee pleaseth, either to good things (according to his mercy,) or to euill (according to their owne desert . . .)." ${ }^{10}$ Yet in other passages these same writers espouse the view that man does have an active role in his redemption. Cole warns that every man must "chiefly ... feare his latter end: For which way the tree falleth, there shall it lye." "We ought," he says, "to take heede to this leaning, as long as the tree continueth standing, and to bend him that way that we desire he should fall." "Similarly Moore remarks, "Why hasten wee not to liue in such sort, as at the day of death wee wish we had. For looke how Death leaueth a man, so shall the last Iudgement finde him." 12 In both cases salvation is now seen to be conditional: man, if he wishes to be saved, has only a limited time to fulfill the responsibilities placed upon him by God.

Another Protestant ars work, William Perkins' very popular $A$ Salve for $a$ Sicke Man (1595), offers an insight into this unsettling contradiction. Like Moore and Cole, Perkins states that "it is not in the power of man to repent when he himselfe will; when God will he may." ${ }^{13}$ Yet he also suggests the importance of human responsibility when elsewhere in the Salve he asks, "Wouldst thou then live eternally? Sue to heaven for they pardon, and see that now in thy life thou die to thine owne sinnes." 14 Explanation for Perkins' apparent religious indecisiveness is found in his Covenant Theology, which, far from being unclear or indecisive, is based on a very carefully worked out concept of election in which salvation depends on the co-action of God and man. ${ }^{15}$ While Perkins never dispenses with predestination, he very much de-emphasizes it, stressing instead that "there is no vertue or gift of God is vs, without our wils." 16

What is important about $A$ Salve for a Sicke Man is that it clearly reflects 


\section{4 / Renaissance and Reformation}

larger developments in the English Church. Perkins might have been the most important spokesman for Covenant Theology, but it was by no means original to him and had widespread acceptance among many English Reformers. Because many other Protestant ars works, including those of Moore and Cole, also incorporate the doctrinal position of the Salve, one might conclude that these works also express to varying degrees this attempt at religious compromise, itself the result of increasing recognition that doctrine must never be an end in itself but must always be subordinated to more important devotional ends. Thus the Protestant ars writers have matters both ways: they appreciate that man cannot passively accept death, that he must have the satisfaction of the struggle, yet they also know that assurance of Grace is man's greatest support in time of trial.

Compromise was not, however, the only solution to the conflict over doctrine, and a second group of Protestant writers believed that the debate would never be totally resolved. Rejecting the dogmatic truth of doctrine, they aimed for widespread appeal by stressing what they perceived as the fundamentals of Christian belief: that man must have faith in God, that he must recognize the magnitude of Christ's sacrifice, and that he must glorify his heavenly Father by living a godly life. This development in the Protestant ars moriendi again might be seen as part of a larger development in the English Church, in this case the Latitudinarianism of the seventeenth century, which found its greatest expression, at least as far as the ars is concerned, in Jeremy Taylor's Holy Dying (1651). ${ }^{17}$ But Taylor was not alone in his call for a return to the "few Doctrines of Christianity, that were ordered to be preached to all the world," ${ }^{18}$ nor was his Holy Dying the only ars work to express this admirable sentiment. Equally effective, if not quite as eloquent, is Christopher Sutton's Disce Mori: Learne to Die (1600), which is written, Sutton says, to move "euery Christian man to enter into a serious remembrance of his ende." 19 Anticipating Taylor, he pointedly states that "experience hath long since taught the world ... howe dangerous it is to saile a ship, where the Pilots are of the disposition to be quarrelling within themselves." ${ }^{20}$ Preoccupation with doctrine, Sutton says, results in "vncharitable censures, in cleane shutting out from the household of faith, and hope of life, those who have poor soules to save."21

Although the emphasis on fundamentals in Sutton and Taylor can be linked to the larger Latitudinarian movement in the English Church, it cannot be totally explained by this context. Another factor that obviously influenced such Protestant ars writers was the subject of death itself. Recognizing that all men regardless of doctrine need to prepare for death, they made a conscious attempt to write in a way that was meaningful to all men. A particularly good example of this purposefulness is Thomas Cranmer's Exhortacion Against the Feare of Death, one of the twelve sermons in the 1547 Book of Homilies and a work that might well be considered a model 
for later writers of the Protestant ars moriendi. Designed to eliminate "the manifold enormities" that had "crept into the Church," 22 the sermons of the Book of Homilies were intended to make Reformist doctrine clear to the ordinary parishioner. For the most part they realize this purpose; there is, for instance, a sermon on justification by faith, one on good works, and another addressing the issue of predestination. By contrast, however, reference in the Exhortacion to specific doctrinal precepts is noticeably absent, and it seems that Cranmer, aware that doctrine is of little importance to the man facing death, consciously limited instruction to one simple message that all Christians could accept: men must live and die "with true fayth, stedfast hope, and perfit charitie."'23

Despite the fundamentally Calvinist framework of the English Church, then, the Protestant ars writers, like their Catholic counterparts, essentially instruct man about how best to prepare for death so he can earn eternal life. This is not, however, their only point of agreement, for both Protestant and Catholic also expand upon the very limited devotional framework of the early Craft of Dying Well. While the Craft focuses specifically on the deathbed and only briefly mentions the idea that dying well is living well, later writers, both Catholic and Protestant, approach preparation for death in the more general sense of Christian living. A typical Protestant work is William Cowper's $A$ Defiance of Death (1623), which considers not only "Strong and notable Comforts to uphold vs in Death," but also "Svndry Heavenly Instructions for a Godly Life." 24 Similarly William Perkins in $A$ Salve for a Sicke Man discusses general preparation for death or the way "a man prepares himself to die through the whole course of his life" 25 and specific preparation or the holy behaviour necessary "in the time of sickeness." 26 The significance of this twofold preparation is obvious: man must not be so foolish as to leave spiritual preparation until the last minute, for only the man who has resisted temptation during life will have the strength to withstand the final trials of the deathbed. What must also be appreciated is that, although these two works single out the specific duties of deathbed preparation, their fundamental thrust is to de-emphasize man's deathbed activities. Moreover, other Protestant ars writers, to counter the misconception that one can willfully procrastinate about spiritual affairs yet still be saved, go even further in reducing the significance of the deathbed. Writers such as Robert Hill in A Direction to Die Well (1606) and George Shawe in The Doctrine of Dying Well (1629) make no mention of the traditional fabric of the Craft, but simply talk about general principles of Christian living and urge the reader to reflect on the commonplace that all of life is a preparation for death.

Although Protestant and Catholic ars writers shared suspicions about deathbed conversion, they clearly disagreed on matters pertaining to the nature and scope of devotional instruction. Compared with a Catholic 


\section{6 / Renaissance and Reformation}

writer such as Bellarmine, who discusses the "art of dying well" in detailed sacramental terms, the Protestant ars writers provide little that is specific, choosing instead to dwell on Christian generalities. This distinction is most noticeable in discussion of deathbed temptation, which is the central feature of, not only the Craft and its medieval derivatives, but also the works of later Catholic writers such as Whiteforde, Erasmus, Verstagen, as well as Bellarmine. No longer does one find extensive instruction on how to withstand the five deathbed temptations, faithlessness, despair, impatience, vain-glory, and avarice. John Moore, for example, reduces deathbed temptation to a general and rather commonplace discussion of the devil, the world, and the flesh. And Christopher Sutton only indirectly considers such temptation by exhorting his reader to the kind of Christian behaviour that strengthens man against the final assaults of Satan; for instance, he urges the reader to Christian "constancie and perseverance"27, rather than elaborating on the temptation to unbelief.

This difference between the Protestant and Catholic ars moriendi is most immediately explained by the general Protestant dislike for the complexities of Catholic liturgy and ritual, and by what has already been identified as a conscious attempt on the part of Protestant ars writers in England to provide devotional assistance to all men of the Reformed Church. A more fundamental reason, though, is that Catholic and Protestant disagreed on the issue of how much man should rely upon the individual conscience in making moral decisions. Although the Catholic Church assigned conscience an important role as moral arbiter, this role was severely limited by a rigorous code of conduct dependent as much on ritual and canon law as on Scripture. Not surprisingly, the English reformers felt such moral law inhibits man's spiritual growth since it not only constitutes an incomprehensible maze far removed from man's spiritual needs, but misleadingly suggests that man need do nothing more to qualify for heaven than follow unthinkingly a set of church laws. The Reform position produced a devotionalism that supplies only general moral guidance, which the individual Christian, with the aid of conscience, must apply to the specific problems of daily life. Quite clearly the Protestant ars moriendi incorporates the view of Bishop Robert Sanderson, which can be taken as the position of the Church of England: "In point of Conscience, there can not be given general rules to meet with all cases, and regulate all differences, than in the point of Law, there can be general resolutions given to set up an end to all suits, or provisions made to prevent all inconveniences. Particulars are infinite, and various; but the rules are not, must not, cannot be so." 28

With this increased role for conscience, it is hardly surprising that awakening man's conscience to sin and the consequences of spiritual unpreparedness is another prominent purpose of the Protestant ars. This meant more, however, than merely saying that preparing to die is the most important of 
man's spiritual responsibilities. To expedite spiritual awareness in the reader, the Protestant ars writers dwell at length upon the four last things (death, judgment, hell, heaven), one of the most basic meditational foci in the Christian tradition. Theological differences aside, they agree with Thomas More that "there is not a more mete instrument than the remembrance of the fowre last thinges, which as they shall pull owte these weedes of flesheleye voluptuousness, so shall they ... plant in their place not onely wholesom virtues, but also marvelous ghosteleye pleasure and spiritual gladness."29

Also fundamental to the Protestant ars moriendi as a means to spiritual awareness is the Calvinist approach to Scripture that sees the Spirit working in man through the literal sense of Scripture provided by logical and grammatical exegesis. Absent from Protestant works on dying well is the fourfold method of scriptural exegesis popular in Catholic devotional literature; Scripture is used only for simple corroboration and illustration. And, concomitant with this basically Calvinist hermeneutic, severe limitations are placed on the imaginative expression so often prominent in Catholic works on preparing for death.

This choice of restraint over exaggeration and of reason over imagination is most noticeable when the Protestants ars writers dwell specifically on the first of the four last things, death. In The Anatomie of Mortalitie (1618), for example, George Strode follows the Aristotelian principles outlined in Thomas Wilson's influential Rule of Reason as he systematically and exhaustively proves that Christ has broken the back of death and given man reason to persevere in Christian preparation; while in $A$ Salve for a Sicke Man Perkins is equally systematic, although he follows Ramus instead of Aristotle. Such rational objectivity is most often revealed, however, in the numerous references to the Ubi Sunt? found in almost every Protestant ars work. The Protestant writers repeatedly dwell on the futility of earthly life in urging the reader to address those matters that constitute preparation for death and whose significance transcends the temporal world. Significant here is how they generally avoid the descriptive excess found, for example, in the Catholic Verstagen's A Dialogue of Dying Well (1603); the Protestant ars writers choose the control of dialectic rather than the exaggerated horrors or the grave to make their point about the transcience and triviality of earthly glory.

The Protestant ars writers aim, then, to mitigate man's fear of death and the spiritual paralysis it causes. John More in A Lively Anatomie of Death (1592) might well speak for the Protestant ars writers generally in noting that his Aristotelian "anatomie" is written so "that the remembrance of Death drive vs not to dispaire, but may rather comfort vs in our conflicts." ${ }^{30}$ For this reason, the Protestant ars writers put less emphasis on the middle pair of the four last things, the horrors of hell and the rigour of God's final judg- 
ment. This is not to say that they ignore them completely; indeed they recognize how fear, if used with discretion, can be a highly effective instrument of persuasion. For example, one sees much of the hellfire preacher in Perkins' Deaths Knell, just as Christopher Sutton typifies Protestant ars writers when he says, "The consideration of Christ his second coming to judgment ought to moue euery one to liue religiously, and to apply himselfe to this lesson of Learning to Dye." ${ }^{31}$ In keeping with man's need for hope in the face of death they generally stress the rewards of preparing for death rather than the punishments of hell or the awfulness of God's judgment.

Also in keeping with this consolatory thrust, many Protestant ars writers dwell at length on the glories of heaven, the culmination of the four last things. This emphasis on the glories of heaven stresses by contrast the vanities of earthly life and reveals the magnitude of God's gift to man which must be requited through the service of God in this world. It is also a departure from the approach the Protestant ars writers use in depicting the other three of the last things. Instead of stressing the literalist hermeneutic of the Calvinists, they fall back on those principles of Ignatian meditation which were generally absent in Protestant devotionalism. As one might expect, these writers basically rely upon the Revelation of John as they attempt to describe the celestial city. They give mere lip service, however, when they say with James Cole, "for the glory of His heavenly place, no man can conceive it." ${ }^{32}$ Although recognizing that language has its own limitations, the Protestant ars writers struggle hard to give their readers some apprehension of heaven, and by means of rhetoric and metaphor they aim to generate in the reader a truly imaginative vision of what awaits the righteous there. John Moore, for example, enthusiastically describes the glories of the world, and then invites his reader to imagine what heaven must be like by comparison:

The ioyes of heauen as farre exceed these prison-ioyes on earth, as Mannah in the Wildernesse did the fleshpots of Egypt; and the bread that the lost sonne ate in his fathers house, the huskes he ate abroad with Swine. They are so great (saith one) that they cannot be measured, so long that they cannot be limited, so many that they cannot be numbered, so precious that they cannot be valued: yet wee shall see them without wearinesse, loue them without measure, and praise them without end. God in creating this transitory world (which yet is but a poore cottage to his eternall habitation) what power, what magnificence, what maiestie hath shewed therein? what glorious heauens, and how wonderfull hath hee created? what infinite Starres, and other Lights hath he deuised? What Elements hath he framed? and how strangely hath hee compact them together? . . . What then shall we conceiue of the house of God, that glorious heauen it selfe? If the cottage of his meanest seruant, (and that made for a time, to beare off (as it were) a showre of raine) be so princely, so glorious, so gorgeous, so full of maiestie (as wee see this world is) what must we think that the Kings Pallace it selfe is? appoynted for all eternitie, for himselfe and his friends to lieu and raigne in for euer. 
Such passages, while clearly straining to capture the indescribable, are especially effective because they markedly contrast with the very carefully measured prose generally characteristic of the Protestant ars moriendi. Certainly they run counter to the commonly held view of the Protestant ars writers that a subject as serious as preparing for death demands the simplest expression. But, as Moore and many others demonstrate, the Protestant ars writers were not unaware of style. One finds in their works a keen awareness of the cadence and rhythm of language, as well as a conscious use of traditional rhetorical devices. This does not mean, however, that style ever becomes complex or convoluted; simplicity is still the most important feature of effective expression, for nothing must ever get in the way of the Christian message. Moreover, the simplicity and directness of such expression produces an earnestness very appropriate to the subject of the ars moriendi, and an exalted mood of consolation for those who recognize in the ars work the true path to salvation.

Whether it be in issues of content or expression, one thing is very clear about the Protestant ars moriendi: it is a literature that was very much alive to the human and spiritual needs of people for whom death was a harsh, often brutal fact of life. This is not to imply that works of the Protestant ars merit entrance into the mainstream of English literature. They do, however, constitute an important tradition in Christian thought, and indeed the proliferation of ars works during the sixteenth and seventeenth centuries itself suggests how crucially important was the task of preparing for death. As well, the English Protestant ars works supply insight into the Renaissance attitude towards death, and reflect the complex spiritual dynamics of the English Church during the sixteenth and seventeenth centuries. Today, of course, these works have been largely forgotten, relegated to the position of relics from a religious age. But such an attitude is unfair, and one must appreciate that the works of the Protestant ars moriendi convey a message of hope that every devout Christian of the age was eager to hear: for the man who prepares properly, death is a gateway to a final reunion with God and a haven for those who suffer long in a corrupt and capricious world.

\section{University of Lethbridge}

Notes

1 William Shakespeare, Measure for Measure, ed. J.W. Lever (London: Methuen \& Co., 1965), III, i, 128-131.

2 Sister Mary Catharine O'Connor, The Art of Dying: The Development of the Ars Moriendi (New York: Columbia University Press, 1942), p. 1.

3 Documented by O'Connor, pp. 101-110.

4 Most important in this regard is Thomas Lupset, $A$ Compendivs and a Very Frvtefvl Treatyse, teachynge the waye of Dyenge Well (London, 1534); for a perceptive analysis of this work, see Katherine Lee Beaty, The Craft of Dying: A Study in the Literary Tradition of the "Ars Moriendi" in England, Yale Studies in English, No. 175 (New Haven and London: Yale University Press, 1970), pp. 56-107. 


\section{0 / Renaissance and Reformation}

5 Thomas Becon, The Sycke Mans Salue (London, 1561), p. 444.

6 William Laud, "The Answer of William, Lord Archbishop of Canterbury, to the Speech of the Lord Say and Seal Touching the Liturgy," in The Works of the Most Reverend Father in God, William Laud, D.D., ed. W. Scott (Oxford: John Henry Parker, 1857), VI, 133.

7 James Cole, Of Death A Trve Description: And against it a good Preparation: Together with A sweet Consolation, for the suruiuing Mourners (London, 1629), p. 120.

8 Ibid., p. 125.

9 John Moore, A Mappe of Mans Mortalitie. Clearly manifesting the originall of Death, with the Nature, Fruits, and Effects thereof both to the Vnregenerate, and Elect Children of God (London, 1617), p. 167.

10 Ibid., p. 25.

11 Cole, p. 62.

12 Moore, p. 175.

13 William Perkins, "A Salve for a Sicke Man," in The Workes of that Famovs and Worthy Minister of Christ, in the Vniuersitie of Cambridge Mr. William Perkins (London, 1612-13), I, 496.

14 Ibid., I, 498.

15 Perkins' two most important works in this regard are $A$ Golden Chain or the Description of Theology (1591) and $A$ Treatise of Gods Free Grace and Mans Freewill (1602).

16 William Perkins, "A Treatise of Gods Free Grace and Mans Freewill" in Workes, I, 738.

17 See Beaty, pp. 197-270.

18 Jeremy Taylor, A Discourse of The Liberty of Prophesying (London, 1647), p. 15.

19 Christopher Sutton, Disce Mori: Learne to Dye (London, 1626), sig. Ar.

20 Ibid., sig. A10v.

21 Ibid., sig. A9r.

22 Certain Sermons, or homilies, appoynted by the kynges Maiestie, to bee declared and redde, by all persones, Vicars, or Curates, euery Sondaye in their churches, where thei haue cure (London, 1547), sig. P2r.

23 lbid., sig. P2r.

24 William Cowper, A Defiance of Death (London, 1623), sig. $\mathrm{A}^{\mathrm{r}}$.

25 Perkins, I, 495.

26 Ibid., I, 499.

27 Sutton, p. 198.

28 Robert Sanderson, “Ad Populum," in The Works of Robert Sanderson, D.D., ed. W. Jacobson (Oxford: The University Press, 1854), III, 125.

29 Thomas More, "A Treatyce (vnfynyshed) vpon these woordes of holye Scrypture, Memorare nouissima, \& ineternum non peccabis," in The Workes of Sir Thomas More Knyght (London, 1557), p. 74.

30 John More, A Lively Anatomie of Death (London, 1596), sig. B3v.

31 Sutton, p. 326.

32 Cole, p. 142.

33 Moore, pp. 160-161. 